\title{
Internal and External Sources of Knowledge in Manufacturing and Service Enterprises A Comparative Analysis of European Union Countries
}

\author{
Joanna Wyszkowska-Kuna \\ Ph.D., University of Lodz, Faculty of Economics and Sociology \\ Department of World Economy and European Integration \\ e-mail: joanna.kuna@uni.lodz.pl
}

\begin{abstract}
Along with the development of economies based on knowledge, the importance of knowledge input in production processes has been increasing. Enterprises may acquire knowledge input by developing their internal knowledge base and/or purchasing knowledge from external entities. Their internal knowledge base may be developed mainly by employing highly qualified specialists and their own research. The aim of the paper is to examine the importance of all these knowledge sources in manufacturing and services enterprises, as well as to compare their changing role with productivity performance in EU countries. It is based on data from the World Input-Output Database, Eurostat, OECD and EU KLEMS. Thanks to the availability of relevant data, the analysed period covers the years 1995-2018. The study demonstrates that knowledge base, developed through both internal and external sources, played a significantly more important role in the EU-15 than in the EU-12, with a tendency to decrease these disparities (most visible with respect to KIBS input). The growing importance of an external knowledge base was more visible and stable in the EU-12 countries. $R \& D$ expenditures were an exception. The recent financial crisis heavily affected only external $R \& D$ expenditures.
\end{abstract}

Keywords: knowledge, R\&D, services, manufacturing, EU

JEL: 014, O47 


\section{Introduction}

In today's knowledge-based economies operating in a competitive global landscape, knowledge is an essential asset, a key for firms' profitability and survival, to a greater extent than traditional production factors (Nonaka 1994; Dean and Kretschmer 2007). Thus, the ability to create and apply new knowledge is considered to be one of the primary sources of competitive advantage (Nonaka 1991; Mu et al. 2008).

Firms need to acquire new knowledge from numerous internal and external sources in order to constantly generate innovations and maintain their competitive edge (Cotic Svetina and Prodan 2008; Santamaria et al. 2009; Basit and Medase 2019). Moreover, the development of knowledge-based economies, the information and communications technology (ICT) revolution, and increased competition made it necessary to reorganise production processes in order to increase their efficiency (Jones and Kierzkowski 1990; Baldwin 2014). As a result, the growing demand for business services (in particular those related to new technologies and knowledge, which are called "knowledge-intensive business services" - KIBS) occurred, as well as the tendency to outsource business services. In the light of this phenomenon, the growing importance of knowledge input acquired from external sources should be expected.

The aim of the paper is to examine the changing role of the internal knowledge base and the acquisition of knowledge from external sources in manufacturing and service enterprises. I proposed three indicators to measure the importance of an internal knowledge base, and two indicators to measure knowledge acquired from external sources. Finally, the average annual growth rates of all indicators are compared with average annual productivity growth in the manufacturing and services sector, measured by total factor productivity (TFP), as the production of new knowledge together with the transmission of the existing knowledge are important drivers of productivity performance (Bostian et al. 2020). To take into account the impact of the recent financial crisis, the analysed period is divided into three sub-periods: 1995-2007, 2008-2010 and 2011-2018/19 (these sub-periods cover different years with respect to different indexes depending on the period for which the relevant data is available). To compare the results for the 'old' and 'new' EU member states, the weighted averages for the EU-15 and the EU-12 are calculated (with weights assigned based on each country's share in the EU-15's and EU-12's output respectively).

The paper is organised as follows. Section 2 reviews the related studies. Section 3 describes the methodology and data source. Section 4 presents and discusses the empirical results. Section 5 concludes. 


\section{Literature review}

High-skilled, professional employees represent the most important internal source of knowledge (Divanna and Rogers 2005; Gabcanova 2011). Based on their internal knowledge base, firms acquire knowledge through in-house R\&D activities and by learning from continuous improvements in business processes. Firms may also develop their knowledge base through education and training.

If firms do not have an appropriate knowledge base inside the firm, they can acquire it externally by cooperating with customers and suppliers, as well as other firms. Among the external sources of knowledge, inter-firm collaboration has received the most widespread research attention, as a consequence of the dynamic development of outsourcing and the offshoring of business services since the 1980s. Nowadays, in order to bring new products, processes and services to the market, firms must mobilise a broad set of skills, which are often beyond their internal capabilities and which include not only technical skills but also market analysis, logistics, and behavioural sciences. Outsourcing and cooperating with other firms enable enterprises to specialise and enhance their competitive advantage (Abramovsky et al. 2004), using their internal knowledge resources optimally and combining them with their partners' specific competencies. In recent years, the range of business services that have been subject to these processes has extended from simple, routine, and standardised tasks to KIBS, such as IT applications, finance and accounting, engineering, R\&D, and human resources (Massini and Miozo 2010; Berchicci 2013; Garavelli et al. 2013).

Firms may acquire knowledge from other private or public firms. In the first case, knowledge input is delivered by firms from the KIBS sector, while in the second case, by universities or public research organisations (Keeble and Wilkinson 2000; Li et al. 2019). KIBS are increasingly recognised as important carriers of new knowledge that is developed in upstream sectors and then diffused into other industries (Schricke et al. 2012), which determines their value added and productivity (Tomlinson 2000; Baker 2007; Wyszkowska-Kuna 2016). KIBS may also be used to translate codified academic knowledge into practical and accessible know-how, to enhance product differentiation, and they may help companies to reduce costs by providing services more cheaply (Di Cagno and Meliciani 2005).

\section{Data and methodology}

The study refers to the manufacturing and service sectors, and thus all indicators are calculated for the manufacturing sector (including all manufacturing divisions, i.e., D15-D37 according to NACE Rev. 1.1 and C10-C33 according to NACE Rev. 2) and for the service sector (including the service divisions except public services, i.e., G50-K74 according to NACE Rev. 1.1 and G45-N80 according to NACE Rev. 2). 
The first indicator takes the form of the share of hours worked by high-skilled persons engaged in total hours worked (HHS). The values of this indicator are presented in WIOD (2013), but they are available for individual manufacturing and service industries. Thus, it was necessary to calculate it for all manufacturing and service sectors, according to the formula:

$$
H H S^{I}=\frac{\sum_{i \in I} H H S_{i} \cdot H E M P_{i}}{\sum_{i \in I} H E M P_{i}} \cdot 100 \%
$$

where HEMP = total hours worked by persons engaged ${ }^{1}$; $I$ denotes the group of industries (i.e. $M$ - the manufacturing sector and $S$ - the service sector); and $i$ denotes divisions according to the NACE classification.

The second index (PROFS) shows the share of Professionals in total employment in manufacturing and services (Eurostat 2020). It can be calculated for the period 2008-2019.

The third indicator measures $\mathrm{R} \& \mathrm{D}$ expenditures in manufacturing and services. It is calculated as the ratio of R\&D expenditures and gross output (ExR\&D/GO - hereinafter called the R\&D index) based on data derived from the OECD STAN Database and Eurostat.

The indicator measuring knowledge acquired from other firms takes the form of the share of KIBS input in total intermediate inputs. It is calculated according to the formula:

$$
I I K I B S^{I}=\frac{\sum_{i \in I} I I K_{i}}{\sum_{i \in I} I I_{i}} \cdot 100 \%
$$

where $I I=$ all intermediate inputs derived from Use tables; IIK = intermediate inputs from KIBS sectors (J62-63 and M69-73); I and $i$ denote as in formula (1). KIBS are defined as including the following divisions: Computer programming, consultancy and related activities; information service activities (J62-63); Legal and accounting activities; activities of head offices; management consultancy activities (M69-70); Architectural and engineering activities; technical testing and analysis (M71); Scientific research and development (M72); Advertising and market research (M73) (Schnabl and Zenker 2013). This indicator measures the acquisition of knowledge input from external entities, which includes knowledge input acquired from both private and public enterprises. Separately, data on R\&D intermediate input (hereinafter denoted as II72), which is a part of IIKIBS, is presented to compare the importance of expenditures on R\&D developed internally and purchased from external sources. The index

1 The term 'persons engaged' is wider than the term 'employees' as it also includes self-employed and family workers (O'Mahony and Timmer 2009). 
is also calculated as the ratio of R\&D intermediate input and gross output - II72/GO (hereinafter called the IIR\&D index) based on the formula:

$$
I I R \& D^{I}=\frac{\sum_{i \in I} I I 72}{\sum_{i \in I} G O} \cdot 100 \%
$$

When calculating the last index, one has to face the problems arising from the change in the classification of R\&D expenditures in national accounts (since 2009). ESA2010 has expanded the range of intellectual property products (intangible assets) by including R\&D. This means that, according to ESA2010, expenditures related to $\mathrm{R} \& \mathrm{D}$ activities are treated as investment expenditures, and not as intermediate consumption (ESA1995). As a result, now both external and internal R\&D are recorded together in the gross fixed capital formation account (GFCF), whereas R\&D intermediate input includes only expenditures incurred by the division M72 (Scientific research and development - they may be called "pure R\&D services"). This means that most external R\&D is excluded from the II72 value.

Moreover, according to ESA1995, external R\&D (II72) used to be assigned to each division - thus, it was possible to calculate their values in manufacturing and services. Since R\&D have been classified in the GFCF account, they refer to the whole economy. Thus, in order to estimate the values of external R\&D in manufacturing and services, first I calculated the shares of II72 that were incurred in manufacturing and services, as well as the shares of external R\&D in total R\&D (external and internal). Such calculations were made for each country in 2007 (the year before the ESA2010 regulations were introduced and before the outbreak of the recent financial crisis). Further, these shares were used to calculate which part of R\&D GFCF should be assigned to external $\mathrm{R} \& \mathrm{D}$, and which part of external R\&D should be assigned to the manufacturing and service sectors. Finally, this value was added to II72 ("pure R\&D services") in manufacturing and services. Such calculations were made for the period 2009-2016. This ensures index comparability in the whole analysed period. The II72 value calculated using this method was also included in the IIKIBS value.

The values of HHS and IIKIBS are calculated based on data from the WIOD database. It covers the period 1995-2009 (2013 Release), and 2000-2014 (2016 Release). The HHS values are available only in the WIOD 2013 Release. The IIKIBS values can be calculated for both periods. One should note, however, that the WIOD 2013 Release was developed based on NACE Rev. 1.1, while the WIOD 2016 Release is based on NACE Rev. 2. As a result, one can notice some changes in the way some services included in the KIBS category are classified. Moreover, data in the WIOD 2016 Release are more disaggregated than those in the WIOD 2013 Release. These change the definition of KIBS, thus making the results incomparable. Finally, one should note that the definition of KIBS according to the WIOD 2016 Release is more relevant as, to a larger extent, it includes only those services that are knowledge-intensive, and therefore 
I used data from the WIOD 2016 Release. Additionally, the ESA Input-Output tables (Eurostat) are used to extend the analysed period till 2016. The data on IIR\&D was derived from the same sources.

Finally, the growth accounting framework (O’Mahony and Timmer 2009) is used to calculate changes in TFP (value-added based, in 2010 prices) on the basis of data derived from the EU KLEMS database (2017).

\section{Empirical results}

In Table 1, the values of the HHS, PROFS and IIKIBS indexes in manufacturing and services in the EU countries are presented. In 2009 their values ranged as follows:

- HHS from 38\% (Ireland) to 6\% (Portugal, Bulgaria, Malta and Romania) in manufacturing and from $46 \%$ (Greece and Ireland) to $14 \%$ (Romania) in services,

- PROFS from 23\% (Finland) to 3\% (Slovakia) in manufacturing and from 27\% (Finland and Sweden) to 15\% (Slovakia) in services,

- IIKIBS from 14\% (Ireland) to 1.5\% (Cyprus) in manufacturing and from 28\% (Belgium) to 6\% (Luxembourg) in services.

The HHS and PROFS indicators increased their values in all EU countries in manufacturing (PROFS except Latvia), and in almost all EU countries in services. The strongest increase in the HHS value took place in Ireland (+23 pp in manufacturing and $+21 \mathrm{pp}$ in services), while the lowest was in Cyprus ( $+1 \mathrm{pp}$ in manufacturing) and in Lithuania (-7.6 pp in services). The PROFS index recorded the highest growth in Finland (+11 pp in manufacturing) and Great Britain ( $+13 \mathrm{pp}$ in services), while the lowest was in Latvia (-0.2 pp in manufacturing) and Greece (+3.8 pp). KIBS input also increased its share in total intermediate inputs in almost all EU-12 countries and most of the EU-15 countries, though the EU-15 average in manufacturing slightly decreased. The strongest increase in the index value can be noticed in Ireland (+6 pp in manufacturing) and Belgium ( $+7.3 \mathrm{pp}$ in services).

All three indexes (Table 1) played a more significant role in the EU-15 than in the EU-12. Particularly high disparities are visible in manufacturing, where the EU-15 average values were about twice higher than those for the EU-12, with the highest disparity in the case of IIKIBS. The disparity between the EU-15 and the EU-12 in services was much less significant. In both groups, one can notice some exceptions - Portugal and Italy reached low values among the EU, while in Estonia (HHS), Lithuania and Slovakia (PROFS in services) and Malta (IIKIBS in services) the situation was the reverse. All indexes (except PROFS) recorded stronger increases in the EU-12 than in the EU-15.

The values of all indexes in services were higher than in manufacturing, with the highest disparity in the case of KIBS input. Moreover, this is more visible in the EU-12 than the EU-15 due to the relatively low values of all indexes in manufacturing in the EU-12 in comparison with the EU-15 countries. 
Internal and External Sources of Knowledge in Manufacturing and Service Enterprises...

Table 1. The values of the HHS, PROFS and KIBS indexes in (\%) and their changes (in pp) in the periods covered by the study in manufacturing and services in the EU countries

\begin{tabular}{|c|c|c|c|c|c|c|c|c|c|c|c|c|}
\hline \multirow{3}{*}{ 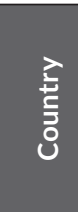 } & \multicolumn{4}{|c|}{ HHS } & \multicolumn{4}{|c|}{ PROFS } & \multicolumn{4}{|c|}{ IIKIBS } \\
\hline & ஓे & 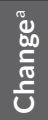 & ஓे & $\begin{array}{l}0 \\
0 \\
\frac{\pi}{\pi} \\
\frac{5}{0} \\
\frac{5}{0}\end{array}$ & 율 & 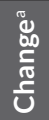 & ㅇํㄹ & 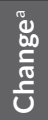 & 웅 & $\begin{array}{l}\stackrel{0}{0} \\
\text { o. } \\
\frac{5}{0} \\
\frac{5}{U}\end{array}$ & 웅 & $\begin{array}{l}0 \\
\stackrel{0}{0} \\
\stackrel{0}{\pi} \\
\frac{5}{U}\end{array}$ \\
\hline & \multicolumn{2}{|c|}{$\mathrm{M}^{\mathrm{b}}$} & \multicolumn{2}{|c|}{$\mathbf{S}^{\mathrm{b}}$} & \multicolumn{2}{|c|}{$M^{b}$} & \multicolumn{2}{|c|}{$\mathbf{S}^{\mathrm{bc}}$} & \multicolumn{2}{|c|}{$\mathrm{M}^{\mathrm{b}}$} & \multicolumn{2}{|c|}{$\mathbf{S}^{b}$} \\
\hline AUT & 15 & 8 & 19 & 8 & 10 & 6 & 18 & 5 & 6 & -0.1 & 22 & 2.6 \\
\hline BEL & 15 & 5 & 32 & 13 & 12 & 5 & 22 & 7 & 7 & 2.1 & 28 & 7.3 \\
\hline DNK & 25 & 11 & 27 & 7 & 15 & 7 & 23 & 7 & 4 & -0.6 & 14 & 1.6 \\
\hline FIN & 32 & 9 & 41 & 5 & 23 & 11 & 29 & 11 & 12 & -2.8 & 19 & 4.7 \\
\hline FRA & 27 & 12 & 39 & 14 & 11 & 0 & 21 & 8 & 10 & 0.3 & 20 & 3.8 \\
\hline GER & 24 & 6 & 30 & 9 & 13 & 4 & 17 & 5 & 7 & -0.5 & 19 & 2.0 \\
\hline GBR & 27 & 11 & 35 & 13 & 20 & 10 & 25 & 13 & 6 & 0.8 & 21 & 1.9 \\
\hline GRC & 14 & 5 & 46 & 15 & 8 & 3 & 18 & 4 & 5 & -1.3 & 8 & 0.7 \\
\hline IRL & 38 & 23 & 46 & 21 & 16 & 5 & 23 & 7 & 14 & 5.7 & 13 & -8.8 \\
\hline ITA & 8 & 5 & 27 & 12 & 5 & 2 & 16 & 4 & 8 & -0.1 & 18 & -0.8 \\
\hline LUX & 23 & 8 & 41 & 19 & 23 & 5 & - & - & 2 & -1.1 & 6 & -0.9 \\
\hline NLD & 22 & 11 & 36 & 15 & 17 & 8 & 25 & 10 & 7 & -4.1 & 21 & -0.4 \\
\hline PRT & 6 & 3 & 15 & 6 & 6 & 4 & 21 & - & 3 & 0.1 & 18 & -0.6 \\
\hline ESP & 31 & 15 & 42 & 19 & 9 & 4 & 15 & 5 & 4 & 0.5 & 13 & 1.8 \\
\hline SWE & 17 & 8 & 29 & 14 & 12 & 3 & 29 & 7 & 10 & -2.6 & 18 & 0.4 \\
\hline BGR & 6 & 3 & 19 & 10 & 5 & 0 & - & - & 2 & 0.5 & 11 & 3.6 \\
\hline CYP & 17 & 1 & 48 & -3 & 8 & 6 & - & - & 2 & 0.2 & 19 & 5.7 \\
\hline CZE & 9 & 3 & 26 & 9 & 6 & 3 & 19 & 5 & 4 & 1.4 & 17 & 3.0 \\
\hline EST & 25 & 4 & 43 & -1 & 9 & 4 & - & - & 4 & -0.6 & 12 & 2.2 \\
\hline HUN & 12 & 4 & 24 & 9 & 8 & 2 & 17 & 5 & 3 & 0.6 & 16 & 2.5 \\
\hline LTU & 22 & 7 & 40 & -8 & 9 & 2 & 22 & 5 & 2 & -0.1 & 11 & 0.5 \\
\hline LVA & 18 & 5 & 33 & -1 & 5 & 0 & - & - & 3 & 0.1 & 13 & 2.8 \\
\hline MLT & 6 & 3 & 18 & 8 & 11 & 5 & - & - & 5 & -2.2 & 23 & 1.9 \\
\hline $\mathrm{POL}$ & 15 & 8 & 35 & 12 & 9 & 3 & 21 & 8 & 4 & 0.0 & 16 & 1.0 \\
\hline ROU & 6 & 3 & 14 & 4 & 9 & 1 & 17 & 4 & 5 & 2.4 & 15 & 6.9 \\
\hline SVK & 8 & 2 & 26 & 10 & 3 & 0 & 15 & - & 3 & 0.0 & 17 & 2.6 \\
\hline SVN & 15 & 6 & 31 & 12 & 11 & 5 & 22 & 9 & 5 & 0.7 & 18 & 0.9 \\
\hline EU15 & 22 & 9 & 34 & 13 & 12 & 4 & 20 & 8 & 7 & -0.2 & 19 & 1.5 \\
\hline EU12 & 12 & 5 & 29 & 9 & 8 & 2 & 19 & 6 & 4 & 0.6 & 16 & 2.1 \\
\hline
\end{tabular}

a Changes in the following periods: HHS 1995-2009; PROFS 2008-2019; IIKIBS 2000-2016.

b $\mathrm{M}$ - manufacturing; $\mathrm{S}$ - services.

c Excluding Accommodation and food service activities; and Real estate activities.

Source: own calculations based on data derived from WIOD 2013, 2016; Eurostat 2020a. 
Table 2. The values of the IIR\&D and R\&D indexes (in \%) and their changes (in pp) in the periods covered by the study in manufacturing and services in the EU countries

\begin{tabular}{|c|c|c|c|c|c|c|c|c|c|c|}
\hline \multirow[b]{3}{*}{ 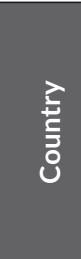 } & \multicolumn{4}{|c|}{ IIR\&D } & \multicolumn{6}{|c|}{$R \& D$} \\
\hline & \multicolumn{2}{|c|}{$M$} & \multicolumn{2}{|c|}{$\mathbf{S}^{a}$} & \multicolumn{3}{|c|}{$M$} & \multicolumn{3}{|c|}{$\mathbf{S}^{a}$} \\
\hline & $\stackrel{\circ}{\circ}$ & 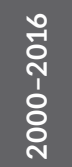 & 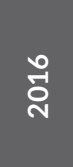 & 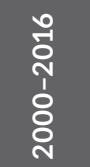 & 휴 & 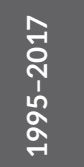 & 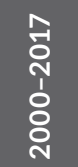 & 궁 & 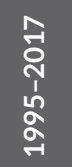 & 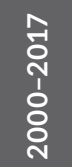 \\
\hline AUT & 0.6 & 0.0 & 0.2 & 0.1 & 2.7 & 0.9 & 0.7 & 0.9 & 0.5 & 0.4 \\
\hline BEL & 1.2 & 0.7 & 0.2 & 0.1 & 2.0 & 0.5 & 0.4 & 0.8 & 0.5 & 0.4 \\
\hline DNK & 0.5 & 0.3 & 0.3 & 0.2 & 3.2 & - & 0.1 & 0.9 & - & -0.3 \\
\hline FIN & 3.3 & -0.2 & 0.1 & -0.1 & 2.2 & 0.5 & -0.3 & 0.8 & 0.4 & 0.2 \\
\hline FRA & 2.6 & -0.4 & 0.3 & -0.1 & 2.1 & - & 0.2 & 0.8 & - & 0.2 \\
\hline GER & 0.7 & 0.0 & 0.1 & 0.0 & 3.0 & 0.5 & 0.4 & 0.4 & 0.3 & 0.2 \\
\hline GBR & 0.4 & 0.1 & 0.3 & 0.1 & 1.9 & - & 0.3 & 0.7 & - & 0.1 \\
\hline GRC & 0.0 & 0.0 & 0.2 & 0.0 & 0.5 & 0.3 & 0.3 & 0.4 & 0.4 & 0.4 \\
\hline IRL & 4.0 & 1.6 & 1.5 & 0.9 & 0.6 & -0.6 & -0.2 & 0.5 & 0.4 & 0.3 \\
\hline ITA & 1.3 & 0.4 & 0.3 & 0.1 & 1.1 & 0.4 & 0.4 & 0.3 & 0.2 & 0.1 \\
\hline LUX & 0.1 & 0.0 & 0.01 & 0.0 & - & 0.0 & 0.0 & 0.1 & - & 0.1 \\
\hline NLD & 1.9 & -1.2 & 0.3 & -0.2 & 1.5 & - & -0.2 & 0.5 & 0.3 & 0.2 \\
\hline PRT & 0.3 & 0.0 & 0.3 & -0.1 & 0.6 & 0.5 & 0.4 & 0.5 & 0.4 & 0.3 \\
\hline ESP & 0.8 & 0.1 & 0.4 & 0.0 & 0.7 & 0.2 & 0.1 & 0.4 & 0.3 & 0.2 \\
\hline SWE & 1.6 & 0.1 & 0.6 & 0.0 & 3.2 & - & 0.2 & 1.3 & - & 0.4 \\
\hline BGR & 0.1 & 0.0 & 0.02 & 0.0 & 0.3 & - & 0.2 & 0.4 & - & 0.3 \\
\hline CYP & 0.0 & 0.0 & 0.04 & 0.0 & 0.4 & - & 0.2 & 0.1 & - & 0.1 \\
\hline $\mathrm{CZE}^{\mathrm{b}}$ & 0.8 & 0.3 & 0.1 & 0.1 & 0.7 & - & 0.1 & 0.6 & - & 0.4 \\
\hline EST & 0.1 & 0.0 & 0.1 & 0.0 & 0.4 & - & 0.0 & 0.4 & - & 0.1 \\
\hline HUN & 0.4 & 0.1 & 0.5 & 0.0 & 0.6 & 0.2 & 0.3 & 0.7 & 0.7 & 0.6 \\
\hline LTU & 0.1 & 0.0 & 0.1 & 0.0 & 0.2 & - & 0.1 & 0.3 & - & 0.2 \\
\hline LVA & 0.1 & 0.0 & 0.3 & -0.1 & 0.2 & - & 0.1 & 0.1 & - & 0 \\
\hline MLT & 0.0 & 0.0 & 0.02 & 0.0 & 0.4 & - & -0.1 & 0.2 & - & 0.1 \\
\hline $\mathrm{POL}$ & 0.3 & 0.0 & 0.2 & 0.0 & 0.4 & 0.1 & 0.1 & 0.5 & 0.4 & 0.5 \\
\hline ROU & 0.2 & 0.0 & 0.2 & -0.1 & 0.2 & -0.3 & -0.1 & 0.2 & 0.1 & 0.2 \\
\hline SVK & 0.1 & -0.2 & 0.2 & -0.2 & 0.4 & 0.1 & 0.2 & 0.2 & -0.1 & -0.1 \\
\hline SVN & 0.7 & -0.1 & 0.3 & -0.1 & 1.6 & 0.9 & 0.8 & 0.5 & 0.4 & 0.2 \\
\hline EU15 & 1.2 & 0.0 & 0.3 & 0.03 & 2.0 & - & 0.3 & 0.6 & - & 0.2 \\
\hline EU12 & 0.4 & 0.1 & 0.2 & -0.02 & 0.5 & - & 0.1 & 0.4 & - & 0.3 \\
\hline
\end{tabular}

a Data on services excluding Real estate (Germany), Transportation and storage (Poland), and Publishing, motion picture, video, television programme production; sound recording, programming and broadcasting activities (Ireland) in the years 2015-2017.

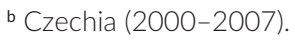

Source: own calculations based on data derived from WIOD 2013, 2016; OECD 2020; Eurostat 2020b.

In Table 2, one can find the values of the two indexes used to compare the role of external and internal expenditures on R\&D activities. Both indexes reached values below 
$1 \%$ in most EU countries in 2016/17. Higher index values can be noticed in the following countries: of IIR\&D in Ireland (both sectors), Belgium, Finland, France, Italy, the Netherlands and Sweden (in manufacturing), and of R\&D in most of the EU-15 countries and Slovakia (in manufacturing) and Sweden (in services). The values ranged as follows:

- IIR\&D from 4\% (Ireland) and 0\% (Greece, Cyprus and Malta) in manufacturing and $1.5 \%$ (Ireland) to $0.01 \%$ (Luxembourg) in services,

- R\&D from 3.2\% (Denmark and Sweden) to 0.2\% (Lithuania and Latvia) in manufacturing and from $1.3 \%$ (Sweden) to $0.1 \%$ (Cyprus and Latvia) in services.

One can notice that internal R\&D expenditures played a more important role than external ones in almost all EU countries with respect to both manufacturing and services. The situation was the reverse only in some of the EU-15 countries (in Ireland in both sectors; in Belgium Finland, France, Italy, the Netherlands, and Sweden in manufacturing; and in Latvia in services).

The values of the IIR\&D index increased or stayed at a similar level in most of the EU countries. A downward trend is visible in six countries. The biggest change in the index value took place in Ireland ( $+1.6 \mathrm{pp}$ in manufacturing and $+0.9 \mathrm{pp}$ in services), while the strongest decline was in the Netherlands (-1.2 pp in manufacturing).

Both indexes recorded much higher values in the EU-15 than in the EU-12 - in the case of IIR\&D, it was three times higher and in the case of $R \& D$, four times higher. This proves that the R\&D disparity between the EU-15 and the EU-12 is much more significant than with respect to the indexes presented in Table 1 . This was the case only in manufacturing.

The IIR\&D index in manufacturing reached four times higher (EU-15) / twice (EU-12) higher values than in services, and the R\&D index in manufacturing recorded three times higher value than in services (EU-15). This proves that R\&D expenditures in manufacturing played a much more important role than in services.

The average annual growth rates of all indexes in the following sub-periods are presented in Table 3. The HHS index increased its value in almost all EU countries through both periods. During the pre-crisis period, the index value declined only in Lithuania and Latvia (in services). What is worth mentioning is that the growth rates during the crisis period were usually significantly higher than during the pre-crisis period (in the EU-12 three/four times higher). The situation was similar regarding the PROFS index, i.e., an upward trend prevailed. During the post-crisis period, the index value declined only in Bulgaria and Latvia (in manufacturing). The index growth rates in the EU-12 were usually higher than in the EU-15, and they usually reached similar values in both periods (except manufacturing in the EU-12 where it increased from 0 to $4 \mathrm{pp}$ ).

As far as the IIKIBS index is concerned, an upward trend prevailed through all periods only in some of the EU countries (7 in manufacturing and 11 in services, mainly the EU-12). In general, the index value increased in most of the EU-12 countries, and the strongest growth took place during the pre-crisis period. One should note that the index growth rates in some of the EU-12 countries were really impressive then (e.g. in manufacturing: 50 pp in Romania, 34 pp in Lithuania, 32 pp in Czechia, 
$25 \mathrm{pp}$ in Hungary; and in services: 58 pp in Romania, $27 \mathrm{pp}$ in Latvia, $22 \mathrm{pp}$ in Bulgaria, 18 in Czechia). As a result, the EU-12 index average growth rates reached the highest values (16 pp in manufacturing and $12 \mathrm{pp}$ in services).

An upward trend continued during the crisis period, but it was much weaker. In the EU-15 countries, the situation was similar, but only regarding the service sector. The index growth rate in manufacturing was negative (due to its sharp decline in Finland and Sweden, as well as a downward trend in three large countries, i.e., Germany, Italy, and Spain). Surprisingly, this trend was reversed already during the crisis period. The post-crisis period was characterised by much higher growth rates than the crisis period (2-3 times higher), though in the EU-12 they did not reach the pre-crisis values. This was the case only in manufacturing as the index growth rates in the services sector declined in the post-crisis period (it even reached a negative value in the EU-15). In general, the index values in the EU-12 were higher than in the EU-15.

During the pre-crisis period, the IIR\&D index declined or did not change its value in almost all EU-15 countries (the average growth rate remained unchanged). The tendency was the reverse in the EU-12, but the average growth rate was low (1 pp). During the crisis period, the index value declined significantly in most of the EU countries (more heavily in the EU-15 and in manufacturing). An upward trend returned in the next period, and what is worth stressing, the growth rates were higher then than in the pre-crisis period. Ireland and Hungary (in manufacturing) and Sweden (in services) stood out due to the relatively high and stable growth rates of both indexes through the whole analysed period. Finally, the R\&D index recorded an upward trend throughout all periods. In some cases, the growth rates were very high. One should note, however, that the index values were usually low and, in such a case, even a small increase (e.g. $+0.1 \mathrm{pp}$ ) may result in a relatively high growth rate. In general, the EU-15 experienced higher growth rates than the EU-12.

To sum up, IIR\&D is the only index that recorded negative growth rates during the crisis period. During the non-crisis periods, the highest growth rates can be assigned to IIKIBS in both groups of countries and to R\&D in the EU-12.

Table 3. Average annual growth rates of the HHS, PROFS, IIKIBS, IIR\&D, R\&D indexes (in pp) in the three sub-periods in manufacturing and services in the EU countries

\begin{tabular}{|c|c|c|c|c|c|c|c|c|c|c|c|c|c|}
\hline Index & \multicolumn{2}{|c|}{ HHS } & \multicolumn{2}{|c|}{ PROFS } & \multicolumn{3}{|c|}{ IIKIBS } & \multicolumn{3}{|c|}{ IIR\&D } & \multicolumn{3}{|c|}{$R \& D$} \\
\hline Period $^{\mathrm{a}}$ & I & II & II & III & I & II & III & I & II & III & I & II & III \\
\hline Country & \multicolumn{13}{|c|}{ Manufacturing } \\
\hline AUT & 6 & 8 & 5 & 6 & 2 & -1 & 5 & -1 & -19 & 4 & 2 & 3 & 4 \\
\hline BEL & 2 & -5 & 2 & 3 & 7 & 28 & 15 & 0 & 8 & 7 & -1 & 4 & 4 \\
\hline DNK & 4 & 5 & 13 & 2 & 0 & -5 & -10 & 7 & -10 & 3 & - & 0 & 1 \\
\hline FIN & 2 & 10 & 9 & 4 & -15 & 10 & -10 & -2 & -31 & -6 & 4 & 8 & -6 \\
\hline FRA & 4 & 5 & 1 & 0 & 4 & -6 & 8 & 0 & -14 & 2 & - & 1 & 2 \\
\hline GER & 2 & 8 & 6 & 1 & -5 & 0 & 8 & -1 & -19 & 2 & -1 & 3 & 3 \\
\hline GBR & 5 & -2 & -1 & 1 & 9 & 6 & 4 & 0 & -15 & -1 & - & -1 & 6 \\
\hline GRC & 4 & -5 & -6 & 2 & 18 & -5 & -19 & - & - & - & 3 & - & 8 \\
\hline
\end{tabular}




\begin{tabular}{|c|c|c|c|c|c|c|c|c|c|c|c|c|c|}
\hline \multirow{2}{*}{$\begin{array}{l}\text { Index } \\
\text { Period }\end{array}$} & \multicolumn{2}{|c|}{ HHS } & \multicolumn{2}{|c|}{ PROFS } & \multicolumn{3}{|c|}{ IIKIBS } & \multicolumn{3}{|c|}{ IIR\&D } & \multicolumn{3}{|c|}{$R \& D$} \\
\hline & I & II & II & III & I & II & III & I & II & III & I & II & III \\
\hline IRL & 6 & 11 & 11 & 1 & 7 & 65 & 30 & 6 & 8 & 8 & -4 & -3 & -3 \\
\hline ITA & 7 & -1 & -4 & 4 & -4 & -2 & 12 & 0 & -28 & 1 & 0 & 9 & 4 \\
\hline LUX & 2 & 46 & -28 & 2 & -31 & 36 & -18 & -4 & 19 & 7 & - & - & - \\
\hline NLD & 5 & 2 & 5 & 4 & 0 & -18 & -15 & 0 & -21 & -1 & -1 & 0 & 2 \\
\hline PRT & 4 & 15 & -5 & 5 & 13 & -1 & -1 & 1 & -28 & -4 & 12 & -1 & 1 \\
\hline ESP & 5 & 6 & 11 & 3 & -2 & 14 & 4 & 0 & -19 & 4 & 3 & -3 & 0 \\
\hline SWE & 6 & 6 & 1 & 3 & -15 & -13 & 11 & -1 & 0 & 7 & - & 4 & -1 \\
\hline BGR & 4 & 15 & 3 & -1 & 15 & 21 & -1 & -4 & -37 & 2 & - & -7 & 33 \\
\hline CYP & 0 & 8 & 10 & 10 & 16 & -11 & -3 & - & - & - & - & -4 & 20 \\
\hline CZE & 2 & 12 & -8 & 9 & 32 & 13 & 5 & 1 & -29 & 5 & -3 & 1 & 5 \\
\hline EST & 1 & 2 & 12 & 4 & -6 & 1 & 4 & 5 & -33 & 5 & - & 50 & -22 \\
\hline HUN & 2 & 5 & 3 & 3 & 25 & -20 & 24 & 3 & 11 & 6 & 2 & 3 & 3 \\
\hline LTU & 2 & 4 & 0 & 1 & 34 & -6 & 3 & 4 & -61 & -1 & - & -3 & 11 \\
\hline LVA & 2 & -10 & 9 & -4 & 16 & -2 & -5 & 0 & -2 & 4 & - & 50 & -3 \\
\hline MLT & 4 & 15 & 2 & 7 & -35 & 4 & 14 & - & - & - & - & -1 & -4 \\
\hline POL & 5 & 9 & 3 & 3 & -4 & 4 & 2 & 2 & -4 & -2 & -7 & 8 & 16 \\
\hline ROU & 4 & 15 & -1 & 1 & 50 & 12 & 7 & 2 & -8 & 9 & -7 & -2 & 1 \\
\hline SVK & 1 & 6 & 6 & 0 & 8 & 3 & 30 & -8 & -17 & 1 & -9 & 24 & 14 \\
\hline SVN & 3 & 12 & 1 & 4 & 4 & 2 & 4 & -1 & -23 & 1 & 3 & 14 & -3 \\
\hline EU15 & 4 & 4 & 3 & 2 & -1 & 2 & 6 & 0 & -18 & 2 & - & 3 & 3 \\
\hline EU12 & 3 & 10 & 0 & 4 & 16 & 4 & 8 & 1 & -13 & 3 & - & 7 & 9 \\
\hline \multicolumn{14}{|c|}{ Services } \\
\hline AUT & 5 & 1 & - & 4 & 9 & 0 & 2 & 1 & -9 & 3 & 7 & 7 & 1 \\
\hline BEL & 3 & 7 & 5 & 4 & 21 & 9 & 6 & -1 & 18 & 5 & 2 & 9 & 7 \\
\hline DNK & 2 & -3 & 4 & 1 & 12 & -4 & -4 & 5 & -12 & 2 & - & -6 & -2 \\
\hline FIN & 1 & 5 & 1 & 3 & 3 & 21 & 7 & -4 & -32 & -11 & 6 & -5 & 1 \\
\hline FRA & 3 & 4 & - & 5 & 11 & 1 & 2 & 1 & -10 & 0 & - & 11 & 0 \\
\hline GER & 2 & 7 & 3 & 1 & 11 & -3 & 3 & -2 & -20 & 1 & 10 & 11 & 3 \\
\hline GBR & 3 & 5 & 3 & 1 & 3 & 1 & -1 & -2 & -28 & -2 & - & 0 & -1 \\
\hline GRC & 2 & 12 & 0 & 1 & 23 & 2 & -4 & 3 & -42 & 0 & 6 & - & 16 \\
\hline IRL & 4 & 1 & 1 & 1 & 3 & -20 & 2 & 16 & -18 & -1 & - & - & -4 \\
\hline ITA & 5 & -4 & -1 & 3 & -2 & 9 & -8 & -1 & 25 & -1 & 9 & 4 & 6 \\
\hline LUX & 3 & 7 & - & - & -27 & 1 & 2 & -9 & 27 & -6 & - & - & - \\
\hline NLD & 4 & 1 & 2 & 3 & 0 & 5 & -10 & -1 & -3 & -2 & 5 & 6 & 0 \\
\hline PRT & 3 & 2 & - & - & -3 & 0 & 3 & -2 & -25 & -2 & 21 & 2 & -2 \\
\hline ESP & 4 & 4 & 3 & 3 & 0 & 16 & 0 & 2 & -35 & 3 & 12 & 13 & -1 \\
\hline SWE & 4 & 3 & -2 & 3 & -6 & 4 & 4 & 3 & 45 & 2 & - & -6 & 9 \\
\hline BGR & 4 & 3 & - & - & 22 & 29 & -1 & -4 & -28 & 1 & - & 69 & 5 \\
\hline CYP & 0 & -1 & - & - & 14 & 2 & 2 & 4 & -7 & -5 & - & -9 & 20 \\
\hline CZE & 2 & 7 & -5 & 5 & 18 & 5 & -5 & 2 & -24 & 9 & - & 8 & 5 \\
\hline EST & -1 & 6 & - & - & 10 & 5 & 7 & 5 & -27 & 3 & - & 9 & -3 \\
\hline HUN & 3 & 1 & 4 & 2 & 9 & 8 & 4 & 0 & -18 & 8 & 18 & 53 & 9 \\
\hline LTU & -1 & 5 & 9 & 3 & 15 & -4 & -6 & 1 & -53 & -2 & - & 28 & 6 \\
\hline
\end{tabular}




\begin{tabular}{|c|c|c|c|c|c|c|c|c|c|c|c|c|c|}
\hline Index & \multicolumn{2}{|c|}{ HHS } & \multicolumn{2}{|c|}{ PROFS } & \multicolumn{3}{|c|}{ IIKIBS } & \multicolumn{3}{|c|}{ IIR\&D } & \multicolumn{3}{|c|}{$R \& D$} \\
\hline Period $^{2}$ & $\mathrm{I}$ & II & II & III & I & II & III & $\mathrm{I}$ & II & III & I & II & III \\
\hline LVA & -2 & 18 & - & - & 27 & 4 & 4 & -2 & 4 & 1 & - & 3 & -2 \\
\hline MLT & 4 & 9 & - & - & -8 & 4 & 4 & -5 & -33 & -4 & - & 17 & 6 \\
\hline $\mathrm{POL}$ & 3 & 12 & 5 & 4 & -1 & 6 & 1 & 3 & 3 & -1 & 8 & 0 & 24 \\
\hline ROU & 2 & 4 & 4 & 1 & 58 & 0 & 0 & -1 & -4 & 5 & -2 & 5 & 11 \\
\hline SVK & 3 & 10 & - & - & 13 & 2 & 21 & -5 & -14 & 1 & -5 & 2 & 6 \\
\hline SVN & 4 & 1 & 1 & 2 & -1 & 5 & 3 & -2 & -22 & 2 & 4 & 41 & -7 \\
\hline EU15 & 3 & 4 & 2 & 3 & 6 & 3 & -0.3 & -0.1 & -11 & 2 & - & 7 & 2 \\
\hline EU12 & 2 & 8 & 3 & 3 & 12 & 5 & 2 & 1 & -11 & 12 & - & 12 & 12 \\
\hline
\end{tabular}

a I-1995-2007 or 2000-2007 (depending on the period for which the relevant data is available); II - 2008-2010; III - 2011-2016/19 (depending on the period for which the relevant data is available. Source: own calculations based on data presented in Tables 1-2.

As far as individual countries are concerned, Ireland and Finland stood out. Ireland recorded the highest values of the following indexes: HHS, IIKIBS (in manufacturing) and IIR\&D, as well as the highest dynamics of IIKIBS (in manufacturing) and IIR\&D. Moreover, it was the only country where external R\&D played a much more important role than internal ones in both sectors. Finland recorded the highest value of PROFS, the second-highest of IIKIBS and among the highest values of other indexes (high dynamics of PROFS in manufacturing and IIKIBS in services, whereas there was a sharp decline of IIR\&D). The relatively high values of all indexes and usually their high dynamics can also be noticed in Great Britain (except IIR\&D in manufacturing) and France.

Among the EU-12, it is more difficult to identify the leading countries, as the variation within this group is usually less visible than in the EU-15. Malta and Slovenia recorded the highest values of PROFS and IIKIBS, Estonia of HHS and Hungary of R\&D (both external and internal). While taking into account the dynamics, Romania stood out with its high growth rates of IIKIBS - during the pre-crisis period it was four times higher (manufacturing) / three times higher (services) than the EU-12 averages. The high growth rates of IIKIBS through all periods can be noticed in Czechia, Hungary (except the crisis period), Romania, Slovakia (only in manufacturing) and in Estonia, Hungary, Latvia, and Slovakia (only in services). Cyprus recorded the highest growth rate of PROFS (only in manufacturing) and Hungary of R\&D (both external and internal).

In Poland, three indexes, i.e., HHS, PROFS and R\&D, recorded higher values and dynamics than the EU-12 average. One should note that during the post-crisis period, Poland experienced the highest growth rate of R\&D in services ( $24 \mathrm{pp}$ ) and its third-highest rate in manufacturing (16 pp), but the R\&D value in manufacturing was still five times lower than the EU-15 average. The IIKIBS values reached the EU-12 average, while its dynamics was usually far below the EU-12 average.

Finally, the Pearson correlation coefficient was used to examine the correlation between the average annual growth rates of each index and TFP in the three following sub-periods (Table 4). The results proved that the growth rates of IIR\&D and PROFS 
were positively correlated with the growth rates of TFP - in the first case, a stronger correlation took place in services, while in the second case, the situation was the reverse. A higher correlation between the growth rates of IIR\&D and TFP in the services sector than in manufacturing is because service companies usually do not have their own research base to conduct their internal R\&D activities, and therefore, they outsource them more often than manufacturing companies.

Table 4. Average annual TFP growth rates in the EU countries in the period 1995-2015 (in pp)

\begin{tabular}{|c|c|c|c|c|c|c|}
\hline \multirow{2}{*}{ Country } & \multicolumn{3}{|c|}{ Manufacturing } & \multicolumn{3}{|c|}{ Services } \\
\hline & 1995-2007 & $2008-2010$ & 2011-2015 & 1995-2007 & 2008-2010 & 2011-2015 \\
\hline AUT & 2.6 & -2.4 & 0.7 & 0.6 & 0.3 & 0.3 \\
\hline DNK & 1.3 & 1.4 & 3.1 & 0.2 & 1.0 & 0.5 \\
\hline FIN & 6.4 & -4.5 & -0.6 & 1.3 & -1.5 & -0.5 \\
\hline FRA & 2.9 & 1.9 & 1.1 & 2.0 & -1.0 & 0.3 \\
\hline GER & 3.1 & 1.1 & 0.5 & 1.3 & -2.0 & 0.8 \\
\hline GBR & 2.3 & 1.8 & -0.1 & 1.1 & 0.6 & 0.7 \\
\hline GRC & 1.0 & -4.6 & 1.1 & 0.4 & -4.5 & 1.7 \\
\hline ITA & 0.5 & 0.2 & 1.0 & -0.2 & -0.8 & 0.2 \\
\hline LUX & 1.4 & -3.8 & 8.5 & 0.5 & 0.1 & -0.5 \\
\hline NLD & 2.8 & -1.3 & 0.6 & 1.0 & -0.9 & 0.9 \\
\hline ESP & 0.0 & -0.6 & 3.0 & -0.6 & -0.7 & 1.1 \\
\hline SWE & 4.0 & 1.3 & -1.1 & 1.1 & -2.5 & 2.2 \\
\hline CZE & 4.8 & 1.3 & -0.4 & 0.7 & -1.6 & 2.4 \\
\hline EST & 0.7 & 3.9 & 3.5 & 4.2 & -0.5 & 1.1 \\
\hline HUN & - & - & 0.3 & - & - & 0.9 \\
\hline LTU & 5.0 & 0.9 & 4.4 & 2.9 & -4.8 & 1.4 \\
\hline POL & 8.4 & 5.3 & 2.2 & 3.1 & 0.0 & -0.8 \\
\hline SVK & 8.4 & 6.5 & 5.9 & 2.4 & -2.2 & 1.2 \\
\hline SVN & 5.3 & -0.2 & 1.1 & 2.1 & -2.8 & 0.7 \\
\hline EU12 & 2.3 & 0.6 & 0.8 & 0.9 & -1.0 & 0.7 \\
\hline EU6/7 & 6.1 & 3.4 & 1.9 & 2.1 & -0.9 & 0.3 \\
\hline
\end{tabular}

GBR - 1997-2007 and 2011-2014; GRC, ITA, SWE-2011-2014; NLD - 2000-2007; EST, LTU, SVN - 2000-2007; POL - 2003-2007; SVK - 2004-2007.

Source: own calculations based on data derived from EU KLEMS 2017.

The negative correlation between the growth rates of $R \& D$ and TFP in services may indicate that the service industries that experience TFP growth (i.e., information and communication services, financial services, retail and wholesale trade, real estate activities - see Wyszkowska-Kuna 2019) shifted from internal to external R\&D activities during the periods covered by the present study. The correlation between these variables in manufacturing companies appeared to be very weak, which may result from the fact that in general the higher TFP growth rates usually occur in less technologically advanced companies that catch up with more advanced companies. One should note, however, that less developed companies do not have their own research 
base, and thus, if they do R\&D activities, they also outsource them. Moreover, there may be other sources of their productivity improvement, as many different factors affect TFP growth (Wyszkowska-Kuna 2016). As far as the growth rates of IIKIBS are concerned, a weak positive correlation with the TFP growth rates is visible but only during the pre-crisis period. While dividing the sample into the EU-15 and EU-12, some better results are obtained for the EU-12, which is due to this group's stronger reliance on external knowledge sources. What came as a surprise is that the correlation was negative in the case of the HHS index. This may be explained as follows: the growing share of high-skilled hours worked resulted in a disproportionate growth of labour input costs, thus leading to the growing contribution of labour input and the decreasing contribution of TFP to valued added growth.

\section{Conclusions}

Based on the study carried out in this paper, a few conclusions can be formulated:

1. Knowledge base, developed through both internal and external sources, played a significantly more important role in the EU-15 than the EU-12, with a tendency to decrease these disparities in most cases (most visible with respect to IIKIBS). The highest disparities referred to $\mathrm{R} \& \mathrm{D}$ expenditures in manufacturing enterprises (both internal and external R\&D), and in general, they were more visible in manufacturing than in service enterprises. Variation within the EU countries was high with respect to all indexes.

2. The development of an internal and external knowledge base took place through all periods covered by the study in both sectors and in both groups of countries. The impact of the recent financial crisis, resulting in lower but - what is worth stressing - still positive growth rates, can be observed regarding KIBS expenditures in service enterprises (in both groups), as well as with respect to the share of professionals in employment and KIBS expenditures in manufacturing (only in the $\mathrm{EU}-12)$. In the EU-12 countries, the post-crisis period restored higher growth rates in these fields, though not always at the pre-crisis level (KIBS expenditure). The opposite trend can be noticed in the case of KIBS expenditures in services. External $R \& D$ expenditures were the only knowledge source that was heavily affected by high negative growth rates during the crisis period. One should note that, at the same time, internal R\&D expenditures enjoyed positive growth rates, meaning that the recent crisis significantly reduced the outsourcing of R\&D activities. Such a trend occurred only during the crisis period as in the following years, the growth rates of expenditures on external R\&D were higher than before the crisis.

3. The growing importance of an external knowledge base is clearly visible in the EU-12 (throughout all periods), whereas in the EU-15 it was less obvious and stable (it occurred in manufacturing in the pre-crisis period and in services in the post-crisis period). The situation was the reverse regarding $R \& D$ expenditures. 
This means that the increasing trend and significance of accessing external suppliers for undertaking R\&D based on contractual modes, which has been discussed at length by innovation scholars (Howells 1999; Gassmann 2006; Martinez-Noya et al. 2012; Kamuriwo and Baden-Fuller 2016), is not confirmed by the findings of the present study.

4. All indexes except R\&D expenditures (both external and internal) recorded higher values in services than in manufacturing. This is due to the fact that, along with the structural transformation towards economies based on knowledge and innovation, the growing use of services, especially those related to knowledge and new technologies, was observed. As a result, knowledge-intensive services, which are classified based on the share of tertiary educated people (Eurostat 2020c), have become the main driving force behind the shift to the new service economy. Moreover, the outsourcing of business services, including knowledge-intensive ones (the process that started before 1995 in high-income countries), reduced the employment of tertiary educated people in manufacturing enterprises. This explains the higher values of HHS and PROFS in services than manufacturing. As far as KIBS input is concerned, one should note that among the industries with the most intensive KIBS intermediate consumption, the following can be mentioned: financial services, telecommunication services, business services, wholesale and retail trade and high-tech manufacturing (Wyszkowska-Kuna 2016). The share of these service industries in the service sector's GDP (defined as including only services of the business economy, as in the present study) is much higher than the hightech manufacturing industries' share in the manufacturing sector's GDP. The opposite trend regarding $R \& D$ expenditures results from a relatively lower reliance on R\&D activities within service enterprises in comparison with manufacturing ones (Wyszkowska-Kuna 2013).

5. Ireland and Finland stood out with the highest importance of knowledge acquired from external and internal sources. Moreover, Ireland was the only country where external R\&D played a much more important role than internal R\&D. This may be due to Ireland's Research and Development Tax Credit ${ }^{2}$, as well as the strong involvement of companies located in Ireland in global value chains, including KIBS and R\&D activities (Wyszkowska-Kuna 2018).

6. In Poland, the development of the internal knowledge base played a more important role than the external one in the periods covered by the present study. All indexes recorded values more characteristic for the EU-12 than the EU-15, quite often at the level lower than the EU-12 average.

7. The growth rates of external R\&D expenditures and professional employment appeared to be positively correlated with productivity performance.

2 The tax (introduced in 2004) aims at encouraging both national and international companies to undertake R\&D activities within Ireland, and it is regarded as one of the best in the world. 


\section{References}

Abramovsky, L., Griffith, R., Sako, M. (2004), Offshoring of business services and its impact on the UK economy, IFS Briefing Note BN51, AIM Briefing Note. https://doi .org/10.1920/bn.ifs.2004.0051

Baker, D. (2007), The impact of business-services use on client industries: evidence from input output data, [in:] L. Rubalcaba, H. Kox (eds), Business Services in European Economic Growth, Palgrave MacMillan, New York, pp. 97-115. https://doi.org/10 .1057/9780230228795_6

Baldwin, R.E. (2014), Trade and Industrialisation after Globalisation's Second Unbundling: How Building and Joining a Supply Chain are Different and Why it Matters, [in:] R.C. Feenstra, A.M. Taylor (eds), Globalisation in an Age of Crisis: Multilateral Economic Cooperation in the Twenty First Century, University of Chicago Press/NBER, Chicago, IL, pp. 165-212. https://doi.org/10.7208/chicago/9780226030890.003.0006

Basit, S.A., Medase, K. (2019), The diversity of knowledge sources and its impact on firm-level innovation. Evidence from Germany, "European Journal of Innovation Management”, 22 (4), pp. 681-714. https://doi.org/10.1108/EJIM-10-2018-0232

Berchicci, L. (2013), Towards an open R\&D system: internal ReD investment, external knowledge acquisition and innovative performance, "Research Policy", 42 (1), pp. 117-127. https://doi.org/10.1016/j.respol.2012.04.017

Bostani, M., Daraio, C., Grosskopf, S., Roucco, G., Weber, W.L. (2020), Sources and uses of knowledge in a dynamic network technology, "International Transactions in Operational Research", 27, pp. 1821-1844. https://doi.org/10.1111/itor.12741

Cotic Svetina, A., Prodan, I. (2008), How Internal and External Sources of Knowledge Contribute to Firms' Innovation Performance, "Managing Global Transitions", 6 (3), pp. 277-299.

Dean, A., Kretschmer, M. (2007), Can ideas be capital? Factors of production in the post-industrial economy: a review and critique, "Academy of Management Review", 32 (2), pp. 573-594. https://doi.org/10.5465/amr.2007.24351866

Di Cagno, D., Meliciani, V. (2005), Do inter-sectoral flows of services matter for productivity growth? An input/output analysis of OECD countries, "Economics of Innovation and New Technology", 14 (3), pp. 149-171. https://doi.org/10.1080/10438 59042000226239

Divanna, J.A., Rogers, J. (2005), People - the new asset on the balance sheet, Palgrave Macmillan, New York. https://doi.org/10.1057/9780230509573

EU-KLEMS (2017), Growth and Productivity Accounts: Statistical Module, ESA 2010 and ISIC Rev 4 Industry Classification, European Commission, Luxembourg.

European System of Accounts - ESA 2010 (2013), European Commission, Luxembourg.

Eurostat (2020a), Labour market: Employment by occupation and economic activity, European Commission, Luxembourg.

Eurostat (2020b), Business expenditures on R\&D (BERD) by NACE Rev. 2, European Commission, Luxembourg ( $5^{\text {th }}$ March 2020).

Eurostat (2020c), Eurostat indicators of High-tech industry and Knowledge-intensive services, Annex 3 - High-tech aggregation by NACE Rev. 2, European Commission, Luxembourg. 
Gabcanova, I. (2011), The Employees - The Most Important Asset in the Organisations, "Human Resources Management \& Ergonomics", V(1).

Garavelli, A.C., Petruzzelli, A.M., Natalicchio, A., Vanhaverbeke, W. (2013), Benefiting from Markets for Ideas - An Investigation Across Different Typologies, "International Journal of Innovation Management”, 17 (6), 1340017. https://doi.org/10.1142 /S1363919613400173

Gassmann, O. (2006), Opening Up the Innovation Process: Towards an Agenda, "R\&D Management”, 36 (3), pp. 223-228. https://doi.org/10.1111/j.1467-9310.2006.00437.x

Howells, J. (1999), Research and Technology Outsourcing and Innovation Systems: An Exploratory Analysis, "Industry and Innovation", 6 (1), pp. 111-129. https://doi .org/10.1080/13662719900000007

Jones, R.W., Kierzkowski, H. (1990), The role of services in production and international trade: a theoretical framework [in:] R.W. Jones, A. Krueger (eds), The Political Economy of International Trade, Basil Blackwell, Oxford, pp. 31-48.

Kamuriwo, D.S., Baden-Fuller, C. (2016), Knowledge Integration Using Product R\&D Outsourcing in Biotechnology, "Research Policy", 45 (5),pp. 1031-1045. https://doi .org/10.1016/j.respol.2016.02.009

Keeble, D., Wilkinson, F. (eds) (2000), High-technology clusters, networking and collective learning in Europe, Ashgate, Aldershot.

Li, X., Gagliardi, D., Miles, I. (2019), Innovation in R\&D service firms: evidence from the UK, “Technology Analysis \& Strategic Management”, 31 (6), pp. 732-748. https:// doi.org/10.1080/09537325.2018.1549729

Martinez-Noya, A., Garcia-Canal, E., Guillen, M.F. (2012), International R\&D Service Outsourcing by Technology-Intensive Firms: Whether and Where?, "Journal of International Management”, 18 (1), pp. 18-37. https://doi.org/10.1016/j.intman.2011 .06 .004

Massini, S., Miozzo, M. (2010), Outsourcing and Offshoring of Business Services: Challenges to Theory, Management and Geography of Innovation, "Manchester Business School Research Paper”, 604. https://doi.org/10.2139/ssrn.1683467

Mu, J., Peng, G., Love, E. (2008), Interfirm networks, social capital, and knowledge flow, "Journal of Knowledge Management", 12 (4), pp. 86-100. https://doi.org/10.11 08/13673270810884273

Nonaka, I. (1991), The knowledge-creating company, "Harvard Business Review", 69 (6), pp. 96-104.

Nonaka, I. (1994), A dynamic theory of organisational knowledge creation, "Organization Science", 5 (1): pp. 14-37. https://doi.org/10.1287/orsc.5.1.14

O’Mahony, M., Timmer, M.P. (2009), Output, Input and Productivity Measures at the Industry Level: the EU KLEMS Database, "Economic Journal”, 119 (538), F374-F403. https://doi.org/10.1111/j.1468-0297.2009.02280.x

Santamaria, L., Nieto, M.J., Barge-Gil, A. (2009), Beyond formal R\&D: Taking advantage of other sources of innovation in low- and medium-technology industries, "Research Policy”, 38 (3), pp. 507-517. https://doi.org/10.1016/j.respol.2008.10.004

Schnabl, E., Zenker, A. (2013), Statistical Classification of Knowledge-Intensive Business Services (KIBS) with NACE Rev.2, evoREG Research Note \#25. 
Schricke, E., Zenker, A., Stahlecker, T. (2012), Knowledge-Intensive (Business) Services in Europe, No EUR 25189: 52, European Commission, Luxembourg.

STAN Database (2020), STAN R\&D Expenditures in Industry (ISIC Rev. 3, ISIC Rev. 4), OECD, Paris (24 ${ }^{\text {th }}$ February 2020).

Tomlinson, M. (2000), The contribution of knowledge-intensive services to the manufacturing industry [in:] B. Andersen, J. Howells, R. Hull, I. Miles, J. Roberts (eds), Knowledge and Innovation in the New Service Economy, Edward Elgar Publishing, Cheltenham, pp. 36-48.

World Input-Output Database (2013), Socio Economic Accounts, European Commission, Luxembourg (24 ${ }^{\text {th }}$ March 2020).

World Input-Output Database (2016), National Input-Output Tables, European Commission, Luxembourg (24 ${ }^{\text {th }}$ March 2020).

Wyszkowska-Kuna, J. (2013), Przyczyny mniejszej aktywności firm usługowych w obszarze działalności innowacyjnej, "Acta Universitatis Lodziensis. Folia Oeconomica: Gospodarka w okresie globalnego kryzysu”, 281, pp. 401-418.

Wyszkowska-Kuna, J. (2016), Usługi biznesowe oparte na wiedzy. Wpływ na konkurencyjność gospodarki na przykładzie wybranych krajów Unii Europejskiej, Wydawnictwo Uniwersytetu Łódzkiego, Łódź,

Wyszkowska-Kuna, J. (2018), The role of import for KIBS intensity: A comparative analysis of European Union countries, "European Journal of Service Management”, 26 (2), pp. 329-336. https://doi.org/10.18276/ejsm.2018.26-41

Wyszkowska-Kuna, J. (2019), Productivity Performance of the Service Sectors in European Union Countries, "Comparative Economic Research. Central and Eastern Europe”, 22 (4), pp. 7-22. https://doi.org/10.2478/cer-2019-0029 


\section{Streszczenie}

\section{Wewnętrzne i zewnętrzne źródła wiedzy w przedsiębiorstwach przetwórczych i usługowych. Analiza porównawcza krajów Unii Europejskiej}

Znaczenie wkładu wiedzy w procesy produkcyjne wzrasta wraz z rozwojem gospodarek opartych na wiedzy. Przedsiębiorstwa mogą nabywać wiedzę poprzez rozwój własnej wewnętrznej bazy wiedzy i/lub przez nabycie wiedzy od zewnętrznych podmiotów. Wewnętrzna baza wiedzy może być rozwijana głównie poprzez zatrudnianie wysoko wykwalifikowanych pracowników oraz prowadzenie własnych badań. Celem pracy jest zbadanie znaczenia tych źródeł wiedzy w przedsiębiorstwach przetwórczych i usługowych, a ponadto porównanie zmieniającej się ich roli ze zmianami w produktywności w krajach UE. Badanie oparte jest na danych pochodzących z World Input-Output Database, Eurostat, OECD i EU KLEMS. Z uwagi na dostępność danych, analizowany okres obejmuje lata 1995-2018. Badanie wykazało, że rozwój bazy wiedzy, zarówno przy udziale źródeł wewnętrznych jak i zewnętrznych, odgrywa dużo większą rolę w krajach UE-15 niż UE-12, z tendencją do zmniejszania się tych dysproporcji (najwyraźniejszą w przypadku wkładu KIBS). Wzrost znaczenia zewnętrznych źródeł wiedzy był bardziej widoczny i stabilny w krajach UE-12 niż UE-15. Wyjątkiem były wydatki na działalność $B \& R$. Wydatki na zewnętrzne $B \& R$ były jedynym źródłem wiedzy, które zostało mocno dotknięte przez ostatni kryzys finansowy.

Słowa kluczowe: wiedza, B\&R, usługi, przetwórstwo, UE 